\title{
Effects of COVID-19 Emergency Response Levels on Air Quality in the Guangdong-Hong Kong-Macao Greater Bay Area, China
}

Special Issue:

Special Issue on COVID-19 Aerosol Drivers, Impacts and Mitigation (X)

\section{OPEN ACCESS}

Received: July 18, 2020

Revised: October 17, 2020

Accepted: October 21, 2020

${ }^{*}$ Corresponding Authors:

Shuping Zha

zhaxp4705@whit.edu.cn

$\mathrm{Nu} \mathrm{Yu}$

nuyu@nuaa.edu.cn

\section{Publisher:}

Taiwan Association for Aerosol Research

ISSN: $1680-8584$ print

ISSN: 2071-1409 online

Copyright: The Author(s). This is an open access article distributed under the terms of the Creative Commons Attribution License (CC BY 4.0), which permits unrestricted use, distribution, and reproduction in any medium, provided the original author and source are cited.

\author{
Jie $\mathrm{Li}^{1}$, Haotian Yang ${ }^{1}$, Shuping $\mathrm{Zha}^{2 *}, \mathrm{Nu} \mathrm{Yu}^{1^{*}}$, Xingang Liu ${ }^{3}$, Ruofei Sun ${ }^{1}$ \\ ${ }^{1}$ College of Civil Aviation, Nanjing University of Aeronautics and Astronautics, Nanjing 211106, \\ China \\ ${ }^{2}$ Wuhu Institute of Technology, Wuhu 241006, China \\ ${ }^{3}$ State Key Laboratory of Water Environment Simulation, School of Environment, Beijing Normal \\ University, Beijing 100875, China
}

\section{ABSTRACT}

The COVID-19 pandemic has affected air quality due to extreme changes in human behavior. We assessed the air quality response to different emergency levels during different COVID-19 periods and the naught period in the Guangdong-Hong Kong-Macao Greater Bay Area (GBA). We obtained the following conclusions: (1) The measures implemented to prevent and control of COVID-19 directly impacted ambient air pollutants. The air quality index and the concentrations of $\mathrm{NO}_{2}, \mathrm{PM}_{2.5}, \mathrm{PM}_{10}$, and $\mathrm{CO}$ in the GBA for 1-19 January 2020 declined $19.4 \%, 16.7 \%, 27.5 \%$, $15.8 \%$, and $25.7 \%$, respectively, compared to the same time period in 2016-2019. (2) The reduction in air pollution was strongly associated with the first-level emergency response during this pandemic. The $\mathrm{AQI}, \mathrm{NO}_{2}, \mathrm{PM}_{2.5}, \mathrm{PM}_{10}, \mathrm{O}_{3}$, and $\mathrm{CO}$ in the GBA decreased by $37.4 \%, 47.0 \%$, $40.5 \%, 44.8 \%, 6.7 \%$, and $24.1 \%$, respectively. We found no statistically significant difference in the concentrations of different pollutants, except for $\mathrm{NO}_{2}$, during the second-and third-level responses. (3) The higher the emergency response level, the greater the $\mathrm{NO}_{2}$ pollutants reduction. The $\mathrm{NO}_{2}$ concentration was reduced by $47.0 \%, 25.5 \%$, and $12.1 \%$ at emergency response levels 1 , 2 , and 3, respectively. The results highlight the importance of understanding the role of emergency response in air quality, and provide reference for authorities to formulate more scientific and reasonable emergency responses to epidemic prevention and control.

Keywords: COVID-19, Pandemic, Emergency response, Air pollution, Guangdong-Hong KongMacao Greater Bay Area (GBA)

\section{INTRODUCTION}

Beginning in December 2019, the world was overwhelmed by an outbreak of the coronavirus disease 2019 (COVID-19). As of 4 October 2020, there have been nearly 35 million confirmed cases of COVID-19 in more than 230 countries, territories, or area, including more than 10 million deaths (WHO, 2020). As an infectious respiratory illness, the symptoms of the COVID-19 include cough, fever, and shortness of breath (WHO, 2020). There is currently no vaccine to prevent COVID-19 infection and the virus is very contagious. In addition, the death rate is fairly high in sensitive populations. At present, the disease is not under control. The best method to prevent infection is to avoid exposure to this virus. To curb the dispersal of the disease from its source, a range of administration intervention and prevention actions, including lockdown, quarantines, travel restrictions, temporary closures of businesses and facilities, and social distancing, have since been implemented, which have been proven to be effective response measures in many countries (Berman and Ebisu, 2020; Muhammad et al., 2020; U.S. EPA, 2020). The COVID-19 pandemic has substantially affected human society, including health care facilities, economic structures, social relationships, and the environment (Bao and Zhang, 2020; Berman and Ebisu, 
2020; Tian et al., 2020; Venter et al., 2020).

Many studies have focused on the effects of COVID-19 pandemic on the environment. A significant decline (reduction of $12.0 \%-52.8 \%$ ) in air pollution was observed in mainland, central, eastern, western, and northern China when the administrative response was implemented to fight the COVID-19 pandemic (Bao and Zhang, 2020; Chen et al., 2020; Filonchyk et al., 2020; Wan et al., 2020; Xu et al., 2020; Zhang et al., 2020a; Zhang et al., 2020b). Similar reductions have been observed in other regions of the world. A $30 \%$ drop in air pollution was recorded over the northeast U.S. (NASA, 2020). The European Environment Agency found a similar large drop in air pollution across European cities (EEA, 2020). The nitrogen dioxide $\left(\mathrm{NO}_{2}\right)$ in Bergamo, Italy, and Barcelona, Spain, on 16-22 March 2020 declined $47 \%$ and $55 \%$, respectively, compared to the same dates in 2019 . $\mathrm{Th} \mathrm{NO}_{2}$ in the U.S. declined $25.5 \%$ during the COVID-19 period (Berman and Ebisu, 2020). Nearly $50 \%$ decreases in $\mathrm{NO}_{2}$, particulate matter $\left(\mathrm{PM}_{10}\right.$, and $\left.\mathrm{PM}_{2.5}\right)$ concentrations were observed in the four metropolitan cities of India during COVID-19 Pandemic Lockdown (Bedi et al., 2020). It was confirmed that the reduction of air pollution was mainly associated with decrease in economic growth and travel restrictions during this pandemic (Bao and Zhang, 2020; Filonchyk et al., 2020).

However, studies on the effects of the emergency response levels on air pollution are lacking. The exogenous shock of the epidemic allowed us to assess the effects of emergency responses on air pollution. We hypothesized that apparent changes in the air quality index (AQI) and air pollutant concentrations during the COVID-19 pandemic would correspond with different response levels, which were determined by different levels of administrative restrictions. This paper has four sections: Section 2 introduces the materials and data source. Section 3 provides the results and discussion, and the paper is concluded in Section 4.

\section{METHODS}

\subsection{Study Area}

The Guangdong-Hong Kong-Macao Greater Bay Area (GBA) consists of two special administrative regions, Hong Kong and Macao, and nine cities in Guangdong province: Guangzhou, Shenzhen, Zhuhai, Foshan, Huizhou, Dongguan, Zhongshan, Jiangmen, and Zhaoging (Fig. 1). It is the $4^{\text {th }}$ largest bay area in the world after the New York Bay Area, San Francisco Bay Area, and Tokyo Bay Area. In 2017, the population of the GBA approached 70 million, and its GDP reached 10 trillion yuan (about USD 1.5 trillion), accounting for $12.2 \%$ of the Chinese national GDP (OGBADPLT, 2019). We focused our analysis on these nine cities in GBA because Guangdong Province government implemented the same emergency responses in these nine cities during the same time frame.

\subsection{Data and Methods}

The government broadcasted air quality index (AQI) and $\mathrm{NO}_{2}, \mathrm{PM}_{2.5}$ and $\mathrm{PM}_{10}$, sulfur dioxide $\left(\mathrm{SO}_{2}\right)$, carbon monoxide $(\mathrm{CO})$, and ozone $\left(\mathrm{O}_{3}\right)$, which are commonly used to assess air quality (Xiao et al., 2018; Bao and Zhang, 2020). In this study, hourly air pollution data between 1 January and 31 May 2020 were collected from the real-time monitoring data system of the Ministry of Ecology and Environment (MEE) (http://datacenter.mee.gov.cn/). The air quality data in the system include $\mathrm{AQI}, \mathrm{NO}_{2}, \mathrm{PM}_{2.5}, \mathrm{PM}_{10}, \mathrm{SO}_{2}, \mathrm{O}_{3}$, and $\mathrm{CO}$. Matched pollution data from 2016 to 2019 were acquired from the National Urban Air Quality Publishing Platform of the China National Environmental Monitoring Centre (CNEMC) (http://106.37.208.233:20035/).

City-level weather conditions data including daily maximum and minimum temperatures, daily maximum wind and gust speeds, and records of rain and snowfall were downloaded online https://freemeteo.cn/weather (Bao and Zhang, 2020).

The public health emergency response policies from Guangdong government were obtained from the website of the Health Commission of Guangdong Province (http://wsjkw.gd.gov.cn). The first COVID-19 case in Guangdong province was reported on 19 January 2020 by the National Health Commission (NHC). To control the COVID-19 pandemic, Guangdong province activated the Level 1 public health emergency response on 23 January 2020. On 9:00 a.m. on 24 February 2020, the emergency response level was lowered from Level 1 to Level 2 and the control measures were adjusted accordingly. The public health emergency response level was lowered to Level 3 as of 9 May 2020. 


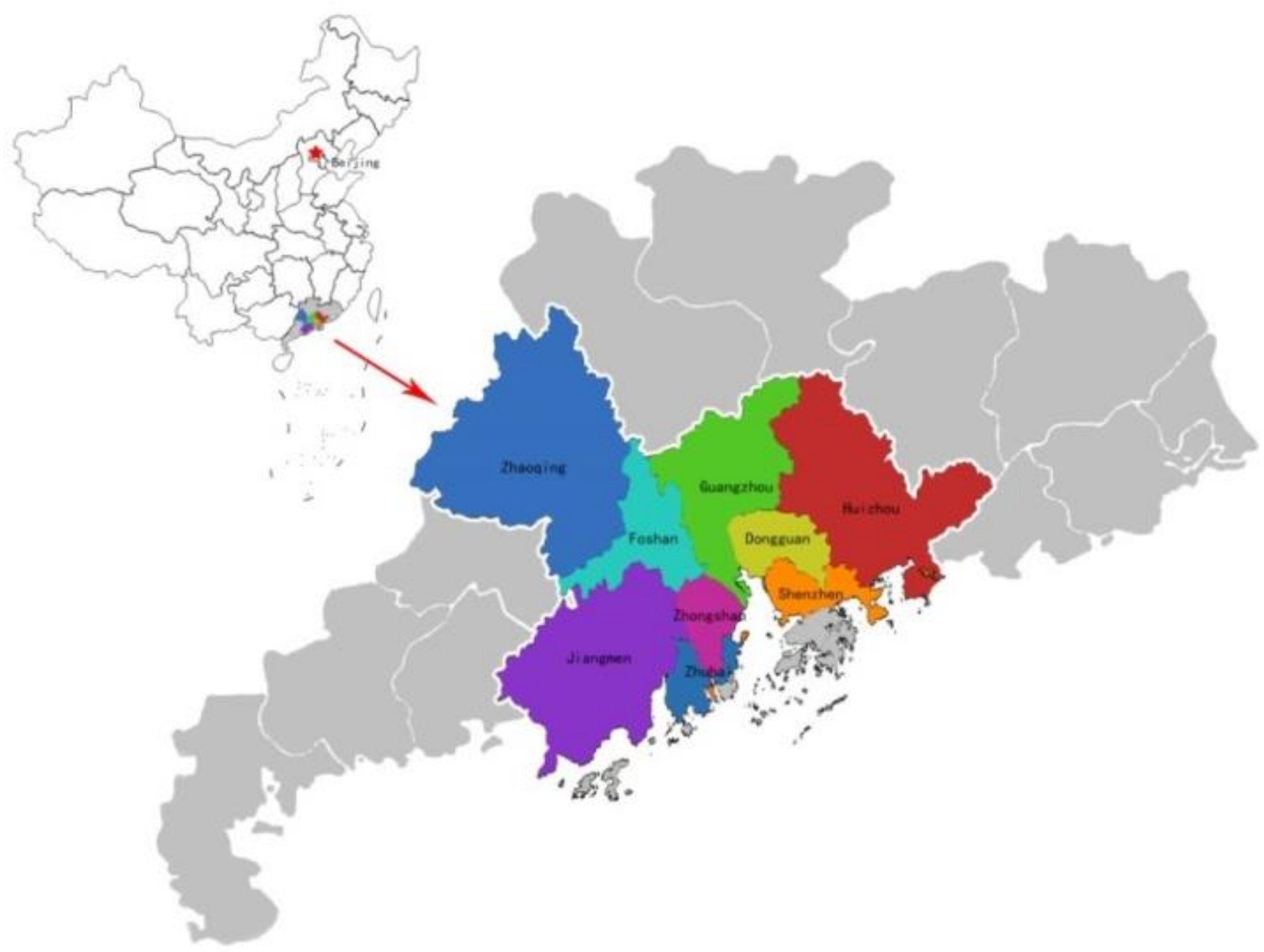

Fig. 1. Study area.

The collected data were organized into two groups: the 2020 data were considered "current" data, and data from 2016 to 2019 were considered "historical" data. Each group was subdivided into four subgroups based on the emergency response levels: the non-COVID-19 period and three different response levels periods under COVID-19. The non-emergency period was chosen from 1 to 19 January 2020. The three days' data from 20 to 22 January were removed to reduce the impact of the first reported case on resident life patterns. The timeframes of the different response levels are listed in Table 1.

Daily averages (i.e., arithmetic mean of a $24 \mathrm{~h}$ monitoring value on a natural day) and moving averages were calculated for these meteorological and air quality data for further analysis and comparison. Student's $t$-test was used for comparing the variables before and after the pandemic.

\section{RESULTS AND DISCUSSION}

\subsection{Difference between Different Scenarios}

When combining all the data from those nine cities, we found that, except for $C O$, the AQI and pollutant levels were significantly different before and after the emergency response policy implementation ( $p<0.05$; Table 2 ), indicating that the social restriction policy applied due to COVID-19 directly impacted pollutants. As long as response measures (regardless of level) are taken, the concentrations of pollutants are affected. However, among the different levels of emergency response, only $\mathrm{NO}_{2}$ concentration showed significant differences for all levels. The 
Table 1. The timeframes of each emergency response levels in Guangdong province for GBA.

\begin{tabular}{lllll}
\hline Groups & Naught & Level 1 & Level 2 & Level 3 \\
\hline Historical (2016-2019) & Same Period & Same Period & Same Period & Same Period \\
Current (2020) & Jan. 01-Jan. 19 & Jan. 23-Feb. 23 & Feb. 24-May 08 & May 09-present* \\
Total days (N) & 19 & 32 & 74 & 23 \\
\hline
\end{tabular}

* The end time was set to May 312020.

Table 2. The significant levels $(\alpha=0.05)$ between different scenes using student t-tests.

\begin{tabular}{lllllll}
\hline Scenes & $\mathrm{AQI}$ & $\mathrm{NO}_{2}$ & $\mathrm{PM}_{2.5}$ & $\mathrm{PM}_{10}$ & $\mathrm{O}_{3}$ & $\mathrm{CO}$ \\
\hline COVID-19 VS Non & 0.00 & $4.44 \mathrm{E}-16$ & 0.00 & 0.00 & 0.00 & 1.00 \\
Level 1 VS Non & 0.003 & $1.36 \mathrm{E}-13$ & $1.54 \mathrm{E}-08$ & $3.04 \mathrm{E}-11$ & $1.22 \mathrm{E}-12$ & 0.29 \\
Level 2 VS Non & $2.19 \mathrm{E}-09$ & $1.87 \mathrm{E}-11$ & $4.32 \mathrm{E}-13$ & $4.15 \mathrm{E}-09$ & 0.00 & 0.89 \\
Level 3 VS Non & $1.0 \mathrm{E}-05$ & 0.02 & $2.00 \mathrm{E}-5$ & $1.2 \mathrm{E}-4$ & $9.3 \mathrm{E}-3$ & 0.13 \\
Level 1 VS Level 2 & 0.14 & 0.00 & 0.87 & $1.6 \mathrm{E}-4$ & 0.55 & 0.14 \\
Level 1 VS Level 3 & 0.97 & $5.00 \mathrm{E}-5$ & 0.07 & 0.27 & 0.82 & $1.88 \mathrm{E}-05$ \\
Level 2 VS Level 3 & 0.16 & 0.04942 & 0.04 & 0.07 & 0.45 & 0.02 \\
\hline
\end{tabular}

concentrations of pollutants under different emergency response levels were significantly different from historical levels prior to the pandemic.

\subsection{Effect of COVID-19 on Air Quality}

In Table 3, we illustrate differences in AQI, $\mathrm{PM}_{2.5}, \mathrm{PM}_{10}, \mathrm{SO}_{2}, \mathrm{NO}_{2}, \mathrm{O}_{3}$, and $\mathrm{CO}$ between current and historical periods in the GBA. The values of $A Q I, \mathrm{NO}_{2}, \mathrm{PM}_{2.5}, \mathrm{PM}_{10}$, and CO from 1-19 January 2020 declined $19.4 \%, 17.0 \%, 27.5 \%, 15.8 \%$, and $25.7 \%$, respectively, compared with the same time periods in 2016-2019. The trends are consistent with the results in other regions in China (Bao and Zhang, 2020; Chen et al., 2020; Filonchyk et al., 2020; Wan et al., 2020; Xu et al., 2020; Zhang et al., 2020a; Zhang et al., 2020b). Different time periods of analysis contribute to the differences of our results from those of other studies.

The main cause of air quality changes is the "Three-Year Action Plan to win the Blue Sky Defense War" implemented by the State Council of China in 2018. The Action Plan goals are to drastically reduce the total emissions of the major air pollutants, along with greenhouse gas emissions, further reducing the concentrations of fine particulate matter $\left(\mathrm{PM}_{2.5}\right)$, significantly reducing the number of days of heavy pollution, and improving air quality.

However, the concentrations of $\mathrm{O}_{3}$ in 2020 have been higher than the historical concentrations. The averages during the no-response periods ("Naught" in Table 3) increased by $26.7 \%$ in 2020. The higher $\mathrm{O}_{3}$ concentrations observed in this study agree with those reported in earlier studies on mainland China (Chen et al., 2020), Europe (Sicard et al., 2020), and India (Bedi et al., 2020). This finding is mainly due to the particularity and complexity of the mechanisms of ozone formation and depletion. Ozone is formed by a photochemical reaction between nitrogen oxides and volatile organic compounds (VOCs) emitted from natural sources and/or human activities (Pyrgou et al., 2018). Certain meteorological conditions such as high temperature, low relative humidity, and high solar radiation are favorable for ozone formation (Lee et al., 2014; Pawalak and Jarosławski, 2015; Li et al., 2019; Bedi et al., 2020; Tan et al., 2020). The average temperature from 1-19 January 2020 in GBA was $3^{\circ} \mathrm{C}$ higher than the matched historical value, while the precipitation was $4 \mathrm{~mm}$ less. More clear days and lower particulate matter concentrations allowed the passage of more sunlight. Higher temperature and stronger illumination, along with increasing photochemical activities, contribute to higher ozone concentrations.

\subsection{Effect of Emergency Response on Air Quality}

The reduction in air pollution was strongly associated with the first level emergency response policy implementation during this pandemic. On average, the AQI decreased by $37.4 \%$, and the five air pollutant concentrations $-\mathrm{NO}_{2}, \mathrm{PM}_{2.5}, \mathrm{PM}_{10}, \mathrm{O}_{3}$, and $\mathrm{CO}$-reduced by $47.0 \%, 40.5 \%$, $44.8 \%, 6.7 \%$, and $24.1 \%$, respectively. 
Table 3. Difference and change (\%) of air pollutants during current and historical for daily means of AQI, $\mathrm{NO}_{2}\left(\mu \mathrm{g} \mathrm{m}^{-3}\right), \mathrm{PM}_{2.5}\left(\mu \mathrm{g} \mathrm{m}^{-3}\right), \mathrm{PM}_{10}\left(\mu \mathrm{g} \mathrm{m}^{-3}\right), \mathrm{O}_{3}\left(\mu \mathrm{g} \mathrm{m}^{-3}\right)$ and $\mathrm{CO}\left(\mathrm{mg} \mathrm{m}^{-3}\right)$ and weather conditions.

\begin{tabular}{|c|c|c|c|c|}
\hline $\begin{array}{l}\text { Air pollutions or weather } \\
\text { conditions }\end{array}$ & $\begin{array}{l}\text { Historical Mean } \\
\text { (S.D.) }\end{array}$ & $\begin{array}{l}\text { Current Mean } \\
\text { (S.D.) }\end{array}$ & Difference & Change (\%) \\
\hline \multicolumn{5}{|l|}{$A Q I$} \\
\hline Naught & $67.2(11.5)$ & $54.1(14.1)$ & -13.1 & -19.4 \\
\hline Level 1 & $53.9(10.7)$ & $33.8(13.9)$ & -20.1 & -37.4 \\
\hline Level 2 & $51.4(9.38)$ & $38.9(14.2)$ & -12.5 & -24.4 \\
\hline Level 3 & $47.2(7.63)$ & $34.4(8.89)$ & -12.8 & -27.1 \\
\hline \multicolumn{5}{|l|}{$\mathrm{NO}_{2}\left(\mu \mathrm{g} \mathrm{m}^{-3}\right)$} \\
\hline Naught & $50.4(6.45)$ & 41.8 (9.79) & -8.6 & -17.0 \\
\hline Level 1 & $31.6(6.49)$ & $16.8(6.41)$ & -14.9 & -47.0 \\
\hline Level 2 & $37.6(7.11)$ & $28.0(8.92)$ & -9.6 & -25.5 \\
\hline Level 3 & $27.3(4.01)$ & $24.0(5.21)$ & -3.3 & -12.1 \\
\hline \multicolumn{5}{|l|}{$P M_{2.5}\left(\mu \mathrm{g} \mathrm{m}^{-3}\right)$} \\
\hline Naught & $46.7(9.26)$ & 33.9(10.94) & -12.82 & -27.5 \\
\hline Level 1 & $36.6(8.10)$ & $21.8(10.34)$ & -14.81 & -40.5 \\
\hline Level 2 & $31.8(6.84)$ & $21.5(8.95)$ & -10.34 & -32.5 \\
\hline \multicolumn{5}{|l|}{$P M_{10}\left(\mu \mathrm{g} \mathrm{m}^{-3}\right)$} \\
\hline Naught & $68.9(12.3)$ & $58.0(14.9)$ & -10.9 & -15.8 \\
\hline Level 1 & $52.6(11.2)$ & $29.1(12.7)$ & -23.6 & -44.8 \\
\hline Level 2 & $52.2(10.8)$ & $38.8(15.1)$ & -13.4 & -25.6 \\
\hline Level 3 & $43.0(6.84)$ & $32.7(9.12)$ & -10.3 & -24.1 \\
\hline \multicolumn{5}{|l|}{$\mathrm{O}_{3}\left(\mu \mathrm{g} \mathrm{m}^{-3}\right)$} \\
\hline Naught & $85.2(14.1)$ & 108(28.6) & 22.7 & 26.6 \\
\hline Level 1 & $94.9(17.6)$ & $88.5(29.7)$ & -6.4 & -6.72 \\
\hline Level 2 & $101(25.3)$ & $102(46.4)$ & 0.8 & 0.83 \\
\hline Level 3 & $138(17.3)$ & $127(29.2)$ & -11.1 & -8.08 \\
\hline \multicolumn{5}{|l|}{$\mathrm{CO}\left(\mathrm{mg} \mathrm{m}^{-3}\right)$} \\
\hline Naught & $1.1(0.06)$ & $0.84(0.13)$ & -0.3 & -25.7 \\
\hline Level 1 & $0.8(0.08)$ & $0.64(0.10)$ & -0.2 & -24.1 \\
\hline Level 2 & $0.8(0.09)$ & $0.62(0.11)$ & -0.2 & -23.2 \\
\hline Level 3 & $0.7(0.06)$ & $0.64(0.10)$ & -0.1 & -9.86 \\
\hline \multicolumn{5}{|l|}{ Temperature $\left({ }^{\circ} \mathrm{C}\right)$} \\
\hline Naught & $19.5(0.69)$ & 23.4(1.05) & 3.9 & 20.0 \\
\hline Level 1 & $19.6(0.60)$ & $21.0(0.88)$ & 1.5 & 7.46 \\
\hline Level 2 & $24.3(0.57)$ & $25.7(0.91)$ & 1.4 & 5.66 \\
\hline Level 3 & $29.6(0.83)$ & $31.3(0.82)$ & 1.7 & 5.59 \\
\hline \multicolumn{5}{|l|}{ Wind $\left(\mathrm{m} \mathrm{s}^{-1}\right)$} \\
\hline Naught & $5.65(0.75)$ & $5.40(0.73)$ & -0.3 & -1.28 \\
\hline Level 1 & $6.32(0.89)$ & $5.87(0.91)$ & -0.4 & -1.90 \\
\hline Level 2 & $5.68(0.81)$ & $5.68(0.82)$ & -0.0 & -0.02 \\
\hline Level 3 & $5.87(1.20)$ & $6.07(1.17)$ & -0.2 & 0.90 \\
\hline \multicolumn{5}{|l|}{ Precipitation (mm) } \\
\hline Naught & $4.3(1.04)$ & $0.2(0.15)$ & -4.1 & -94.9 \\
\hline Level 1 & $4.7(1.98)$ & $3.7(0.92)$ & -1.6 & -21.7 \\
\hline Level 2 & $7.6(1.40)$ & $2.7(1.32)$ & -4.9 & -64.3 \\
\hline Level 3 & $13.3(2.06)$ & $7.6(4.94)$ & -5.7 & -42.7 \\
\hline
\end{tabular}

The average wind speed from 23 January-24 February 2020 was $0.44 \mathrm{~m} \mathrm{~s}^{-1}$ lower than the matched period record and the average precipitation was $1.6 \mathrm{~mm}$ lower. The low wind speed and light precipitation do not help with the diffusion and wet deposition of pollution. Under the same meteorological conditions as in the historical records, the improvement of air quality of each response level was expected to be more obvious than in current situation. Improvements in air 
quality will reduce the spread of the COVID-19 infection and play a positive role in the prevention and control of the epidemic (Wang et al., 2020; Zhu et al, 2020).

The first level emergency response was ordered and implemented by the State Council, and the provincial governments organized and coordinated the provincial emergency response under unified leadership and command. The intervention and prevention actions included travel restrictions, restricting gathering activities of people in markets and public areas, temporary closures of businesses and facilities, and lockdown. The $\mathrm{AQI}, \mathrm{NO}_{2}, \mathrm{PM}_{2.5}, \mathrm{PM}_{10}$, and $\mathrm{CO}$ in northern China decreased by $7.80 \%, 24.7 \%, 5.93 \%, 13.7 \%$, and $4.58 \%$, respectively, due to the implementation of travel restrictions only (Bao and Zhang, 2020). The results in this study show that the air environment in these nine cities in the GBA was more easily affected by this policy than that in northern China.

During the second- and third-level response periods, $\mathrm{AQI}, \mathrm{PM}_{2.5}$, and $\mathrm{PM}_{10}$ pollutants were $32.5 \%-9.86 \%$ lower than the historical average of the same period, with an average reduction of $24.7 \%$. However, the differences were not statistically significant except for $\mathrm{NO}_{2}$ during level 2 and 3 responses. The differences in the reduction rates of $A Q I, \mathrm{PM}_{2.5}$, and $\mathrm{PM}_{10}$ between level 2 and 3 periods were only $2.74 \%$ (from $24.4 \%$ to $27.1 \%$ ), $-1.51 \%$ (from $32.5 \%$ to $31.0 \%$ ), and $-1.53 \%$ (from $25.6 \%$ to $24.1 \%$ ), respectively (Table 3 ).

The second level response was deployed by the provincial government, whereas the third level response plan was designed by the city and county governments. As of 24 February, the response to the public health emergency in Guangdong province was lowed to level 2, which meant all business could scientifically and reasonably reopen, and production and living order could be resumed, but gathering and collective activities were reduced.

$\mathrm{NO}_{2}$ is the most sensitive pollutant species amongst those included in our investigation (Fig. 2(b)). The higher the emergency response level, the higher the observed $\mathrm{NO}_{2}$ reduction. The $\mathrm{NO}_{2}$ concentration was reduced by $47.0 \%, 25.5 \%$, and $12.1 \%$ at levels 1,2 , and 3, respectively, and all differences are significant. In the ambient environment, the sources of $\mathrm{NO}_{2}$ mainly include fuel combustion, automobile exhaust, and industrial production process. With the relaxing of emergency response restrictions and the restoration of normal production and living order, $\mathrm{NO}_{2}$ increased again.

The CO concentration showed a downward trend during the period of epidemic prevention and control, similar to that of the $\mathrm{CO}$ trend in the same period in previous years. During the period of epidemic prevention and control, the CO concentration decreased by $24.1 \%-9.86 \%$ due to the emergency response policies contributing to the reduction of human activities. The $\mathrm{CO}$ concentration decreased by $24.1 \%$ and $23.2 \%$ at levels 1 and 2 , respectively, but the differences are not significant (Fig. 2(f)).

The source of $\mathrm{CO}$ in the atmosphere is mainly the incomplete combustion of fossil fuels and biofuels. During the epidemic control period, the $\mathrm{CO}$ emitted by civil boilers and power stations was significantly affected (Wan et al., 2020). During the first-level response period after the outbreak of the epidemic, severe strict restrictions were imposed in Guangdong province. The $\mathrm{CO}$ emissions from industrial and traffic activities decreased significantly, while the CO emission from the daily life sector remained steady. China was in the Spring Festival holidays at that time. The festival involves traditional customs such as setting off fireworks and firecrackers and burning sacrifices. The response policy mainly restricted industrial and traffic activities, but did not restrict firework and burning activities. The reduction of $\mathrm{CO}$ was not very obvious during the third-level response period, which was mainly due to the work and production resuming along with restoration of daily activities.

\section{CONCLUSIONS}

An unprecedented lockdown in response to the COVID-19 pandemic brought almost all activities to a standstill in China. To slow or stop the spread of COVID-19, Guangdong province implemented different public health emergency response levels. The exogenous shock enabled us to assess the effects of these emergency responses on air pollution. Our analysis focused on the air quality changes as a result of different emergency response levels. By investigating the associations between the air pollution data, the emergency responses levels, and meteorological conditions, we obtained the following conclusions: 

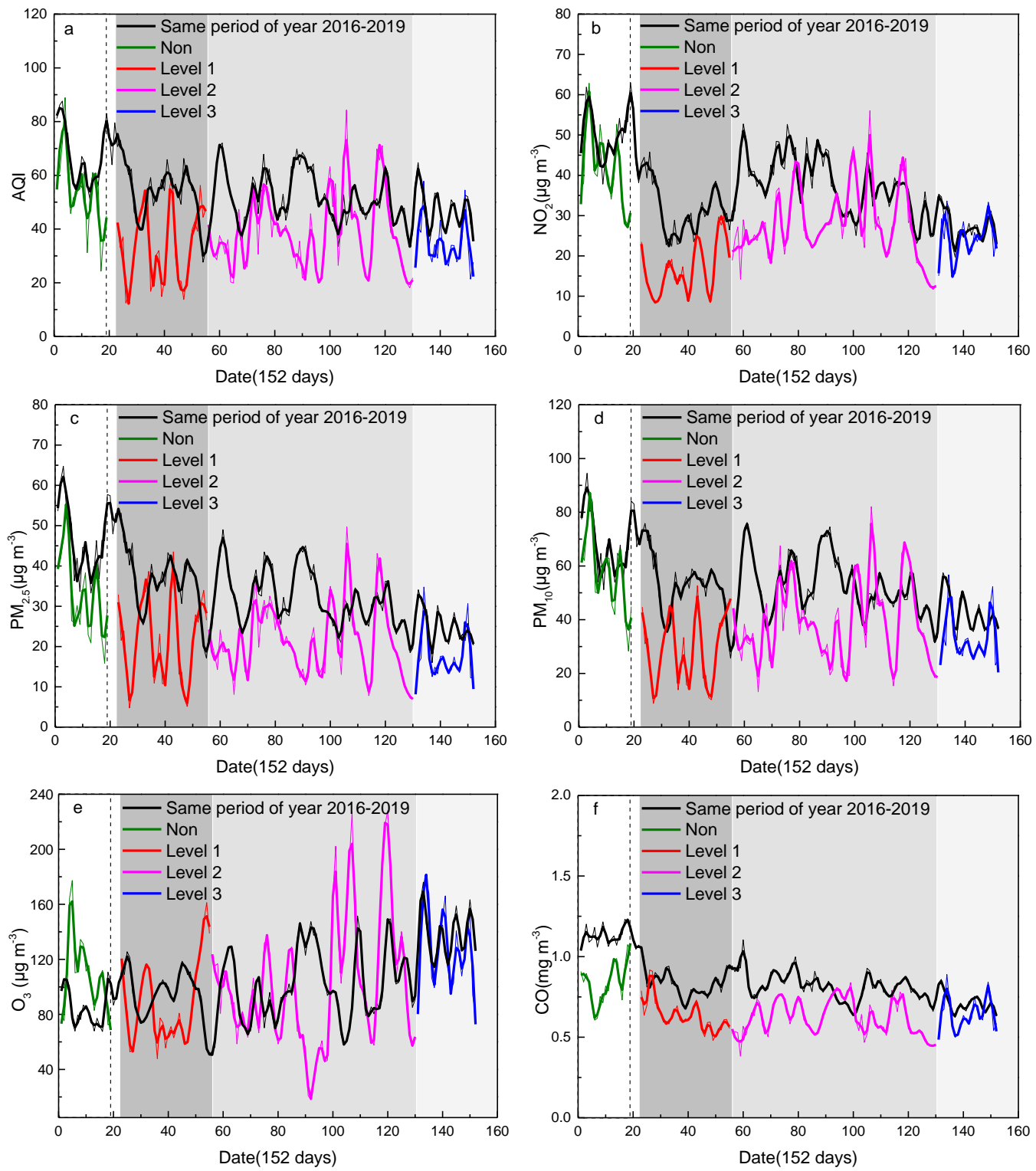

Fig. 2. The time series of (a) air quality index (AQI), (b) $\mathrm{NO}_{2}$, (c) $P M_{2.5}$, (d) $P M_{10}$, (e) $\mathrm{O}_{3}$, and (f) $\mathrm{CO}$ during different emergency response levels.

1. The measures implemented to prevent and control COVID-19 directly impacted ambient air pollutants. The AQI and the concentrations of $\mathrm{NO}_{2}, \mathrm{PM}_{2.5}, \mathrm{PM}_{10}$, and $\mathrm{CO}$ in the GBA from 119 January 2020 declined $19.4 \%, 17.0 \%, 27.5 \%, 15.8 \%$, and $25.7 \%$, respectively, compared to the same time period in 2016-2019. The anthropogenic emissions were reduced due to these measures, and a significant decrease in pollutant concentrations compared with the same period in previous years was observed.

2. The reduction in air pollution was strongly associated with the first-level emergency response during this pandemic. The AQI, $\mathrm{NO}_{2}, \mathrm{PM}_{2.5}, \mathrm{PM}_{10}, \mathrm{O}_{3}$, and $\mathrm{CO}$ in the GBA decreased by $37.4 \%, 47.0 \%, 40.5 \%, 44.8 \%, 6.72 \%$, and $24.1 \%$, respectively. During the first-level emergency response period, most of the enterprises shut down, businesses and facilities were temporary closed, and travel was restricted, resulting in obvious declines of various pollutions.

3. We found no statistically significant difference in the concentrations of different pollutants, except for $\mathrm{NO}_{2}$, during the second- and third-level responses. With regard to $\mathrm{NO}_{2}$, the higher the emergency response level, the greater the reduction in pollutants. The $\mathrm{NO}_{2}$ concentration was reduced by $47.0 \%, 25.5 \%$, and $12.1 \%$ at emergency response levels 1,2 , and 3 , 
respectively. During the second- and third-level responses, the enterprises reopened, production restarted, and residents returned to their daily living activities. Anthropogenic pollutants gradually increased, which led to similar pollutant levels between the current year and the same period in previous years.

From the results in this study, we provide the following suggestions for policy makers:

1. To ensure both epidemic control and economic recovery, appropriate response levels can be adopted to deal with the epidemic according to the local situations.

2. Air pollution in the GBA is severely affected by anthropogenic emissions. Human behavioral changes are promising measures to reduce anthropogenic emissions and improve the ambient air quality.

Further studies are necessary for understanding the detailed associations among air pollution, emergency responses levels, and the meteorological conditions to help the policy maker formulate more scientific and reasonable strategies for air pollution control.

\section{DISCLAIMER}

The authors declare that they have no known competing financial interests or personal relationships that could have appeared to influence the work reported in this paper. The opinions expressed in this article are those of the authors and do not represent those of their affiliations.

\section{ACKNOWLEDGEMENTS}

This work was supported by National Natural Science Foundation of China (Nos. 91544232, 41475109, 41601189, 41701634), Key research projects of Natural Science in Colleges and universities of Anhui Province (No. KJ2019A0984), China-EU Science \& Technology Cooperation Program (No. MJ-2020-S-03), Causes of heavy air pollution and tackling key projects (No. DQGG05-32), Science and technology innovation team project (No. wzykjtd202001), Cultivation project of science and technology innovation service platform (No. Kjcxpt202007). Besides, we greatly appreciated the fund support from Nanjing University of Aeronautics and Astronautics New Faculty Startup Funding (No. 90YAH19018).

\section{REFERENCES}

Bao, R., Zhang, A. (2020). Does lockdown reduce air pollution? Evidence from 44 cities in northern China. Sci. Total Environ. 731, 139052. https://doi.org/10.1016/j.scitotenv.2020.139052

Bedi, J.S., Dhaka, P., Vijay, D., Aulakh, R.S., Gill, J.P.S. (2020). Assessment of air quality changes in the four metropolitan cities of India during COVID-19 pandemic lockdown. Aerosol Air Qual. Res. 20, 2062-2070. https://doi.org/10.4209/aaqr.2020.05.0209

Berman, J.D., Ebisu, K. (2020). Changes in U.S. air pollution during the COVID-19 pandemic. Sci. Total Environ. 739, 139864. https://doi.org/10.1016/j.scitotenv.2020.139864

Chen, Q.X., Huang, C.L., Yuan, Y., Tan, H.P. (2020). Influence of COVID-19 event on air quality and their association in Mainland China. Aerosol Air Qual. Res. 20, 1541-1551. https://doi.org/10. 4209/aaqr.2020.05.0224

European Environmental Agency (EEA) (2020). Air pollution goes down as Europe takes hard measures to combat coronavirus. https://www.eea.europa.eu/highlights/air-pollution-goesdown-as (accessed 4 June 2020).

Filonchyk, M., Hurynovich, V., Yan, H., Gusev, A., Shpilevskaya, N. (2020). Impact assessment of COVID-19 on variations of $\mathrm{SO}_{2}, \mathrm{NO}_{2}, \mathrm{CO}$ and $\mathrm{AOD}$ over east China. Aerosol Air Qual. Res. 20, 1530-1540. https://doi.org/10.4209/aaqr.2020.05.0226

Health Commission of Guangdong Province (2020). http://wsjkw.gd.gov.cn/zwyw_yqxx/ind ex.html (accessed 4 June 2020).

Lee, Y.C., Shindell, D.T., Faluvegi, G., Wenig, M., Lam, Y.F., Ning, Z., Hao, S., Lai, C. (2014). Increase of ozone concentrations, its temperature sensitivity and the precursor factor in south China. Tellus B 66, 23455. https://doi.org/10.3402/tellusb.v66.23455 
Li, K., Jacob, D.J., Liao, H., Shen, L., Zhang, Q., Bates, K.H. (2019). Anthropogenic drivers of 20132017 trends in summer surface ozone in China. Proc. Natl. Acad. Sci. U.S.A. 116, 422-427. https://doi.org/10.1073/pnas.1812168116

Muhammad, S., Long, X., Salman, M. (2020). COVID-19 pandemic and environmental pollution: A blessing in disguise? Sci. Total Environ. 728, 138820. https://doi.org/10.1016/j.scitotenv.202 0.138820

National Aeronautics and Space Administration (NASA) (2020). Data show 30 percent drop in air pollution over northeast U.S. https://climate.nasa.gov/news/2970/nasa-satellite-data-show30-air-pollution-drop-over-the-northeastern-us/ (accessed 5 July 2020).

Office of the Guangdong-Hong Kong-Macao Greater Bay Area Development Promotion Leader Team (OGBADPLT) (2020). About the Guangdong-Hong Kong-Macao Greater Bay Area. http://www.cnbayarea.org.cn/introduction/content/post_165071.html (accessed 4 June 2020).

Pyrgou, A., Hadjinicolaou, P., Santamouris, M. (2018). Enhanced near-surface ozone under heatwave conditions in a Mediterranean Island. Sci. Rep. 8, 9191. https://doi.org/10.1038/s41 598-018-27590-z

Sicard, P., De Marco, A., Agathokleous, E., Feng, Z., Xu, X., Paoletti, E., Rodriguez, J.J.D., Calatayud, V. (2020). Amplified ozone pollution in cities during the COVID-19 lockdown. Sci. Total Environ. 735, 139542. https://doi.org/10.1016/j.scitotenv.2020.139542

Tan, Z., Hofzumahaus, A., Lu, K., Brown, S.S., Holland, F., Huey, L.G., Kiendler-Scharr, A., Li, X., Ma, N., Min, K.E., Rohrer, F., Shao, M., Wahner, A., Wang, W., Wiedensohler, A., Wu, Y., Wu, Z., Zeng, L., Zhang, Y., Fuchs, H. (2020). No evidence for a significant impact of heterogeneous chemistry on radical concentrations in the north China plain in summer 2014. Environ. Sci. Technol. 54, 5973-5979 https://doi.org/10.1021/acs.est.0c00525

Tian, H., Liu, Y., Li, Y., Wu, C.H., Chen, B., Kraemer, M.U.G., Li, B., Cai, J., Xu, B., Yang, Q., Wang, B., Yang, P., Cui, Y., Song, Y., Zheng, P., Wang, Q., Bjornstad, O.N., Yang, R., Grenfell, B.T., ... Dye, C. (2020). An investigation of transmission control measures during the first 50 days of the COVID-19 epidemic in China. Science 368, 638-642. https://doi.org/10.1126/science.abb6105

United States Environmental Protection Agency (U.S. EPA). (2020). EPA announces enforcement discretion policy for COVID-19 pandemic. https://www.epa.gov/newsreleases/epaannounces-enforcement-discretion-policy-covid-19-pandemic (accessed 4 June 2020).

Venter, Z.S., Aunan, K., Chowdhury, S., Lelieveld, J. (2020). COVID-19 lockdowns cause global air pollution declines with implications for public health risk. medRxiv 2020.04.10.20060673. https://doi.org/10.1101/2020.04.10.20060673

Wan, S., Cui, K., Wang, Y.F., Wu, J.L., Huang, W.S., Xu, K., Zhang, J. (2020). Impact of the COVID19 event on trip intensity and air quality in southern China. Aerosol Air Qual. Res. 20, 17271747. https://doi.org/10.4209/aaqr.2020.07.0364

Wang, P., Chen, K., Zhu, S., Wang, P., Zhang, H. (2020). Severe air pollution events not avoided by reduced anthropogenic activities during COVID-19 outbreak. Resour. Conserv. Recycl. 158, 104814. https://doi.org/10.1016/j.resconrec.2020.104814

World Health Organization (WHO) (2020). Coronavirus disease (COVID-19) outbreak. https://w ww.who.int/emergencies/diseases/novel-coronavirus-2019 (accessed 19 July 2020).

Xiao, K., Wang, Y., Wu, G., Fu, B., Zhu, Y. (2018). Spatiotemporal characteristics of air pollutants $\left(\mathrm{PM}_{10}, \mathrm{PM}_{2.5}, \mathrm{SO}_{2}, \mathrm{NO}_{2}, \mathrm{O}_{3}\right.$, and $\mathrm{CO}$ ) in the Inland Basin City of Chengdu, Southwest China. Atmosphere 9, 74. https://doi.org/10.3390/atmos9020074

Xu, K., Cui, K., Young, L.H., Hsieh, Y.K., Wang, Y.F., Zhang, J., Wan, S. (2020). Impact of the COVID19 event on air quality in Central China. Aerosol Air Qual. Res. 20, 915-929. https://doi.org/10. 4209/aaqr.2020.04.0150

Zhang, J., Cui, K., Wang, Y.F., Wu, J.L., Huang, W.S., Wan, S., Xu, K. (2020a). Temporal variations in the air quality index and the impact of the COVID-19 event on air quality in Western China. Aerosol Air Qual. Res. 20, 1552-1568. https://doi.org/10.4209/aaqr.2020.06.0297

Zhang, L., Yang, L., Zhou, Q., Zhang, X., Xing, W., Zhang, H., Toriba, A., Hayakawa, K., Tang, N. (2020b). Impact of the COVID-19 outbreak on the long-range transport of particulate PAHs in East Asia. Aerosol Air Qual. Res. 20, 2035-2046. https://doi.org/10.4209/aaqr.2020.07.0388

Zhu, Y., Xie, J., Huang, F., Cao, L. (2020). Association between short-term exposure to air pollution and COVID-19 infection: Evidence from China. Sci. Total Environ. 727, 138704. https://doi.org/10.1016/j.scitotenv.2020.138704 